ACTA UNIVERSITATIS LODZIENSIS

FOLIA LITTERARIA POLONICA 4(34) 2016

http://dx.doi.org/10.18778/1505-9057.34.21

Jolanta Kowal*

\title{
Rola wileńskiego typografa Józefa Zawadzkiego w rozwoju czasopiśmiennictwa polskiego na Litwie w epoce porozbiorowej
}

\begin{abstract}
„Pospolicie z pism periodycznych sądzą o stopniu narodowej instrukcji.
To mając na względzie, spodziewać się potrzeba, że kochający honor narodowy zechcą wspierać przedsięwzięcia w tej mierze i nie będą nazywać zbytkiem, kiedy kilka pism periodycznych wychodzić zacznie"1.
\end{abstract}

Józef Zawadzki przybył do Wilna w 1803 roku, a więc w czasie, gdy stolica Litwy zaczęła coraz intensywniej wypracowywać pozycję cenionego ośrodka kulturalno-naukowego. Sprzyjała temu dość liberalna polityka, jaką początkowo stosował wobec swoich nowych poddanych car Aleksander I. Najwymowniejszym jej dowodem było ustanowienie na bazie Szkoły Głównej Wielkiego Księstwa Litewskiego - Cesarskiego Uniwersytetu Wileńskiego. Sprawował on naukową pieczę nad wszystkimi typami szkół utworzonego podówczas Wileńskiego Okręgu Naukowego. Na jego kuratora wyznaczono księcia Adama Jerzego Czartoryskiego, który cieszył się szczególnym zaufaniem włodarza Rosji. Stolica Litwy stała się wtedy, bez wątpienia, jednym z najaktywniejszych intelektualnie środowisk na byłych ziemiach polskich. Według Tadeusza Turkowskiego, „w szeregu ognisk życia duchowego polskiego po rozbiorach Wilno wypełniło zadania szczególnie ważne. Skupiwszy w swoich murach uniwersyteckich najlepsze siły naukowe kraju, uratowało i doprowadziło do rozkwitu ruch naukowy epoki stanisławowskiej. Rządząc szkolnictwem olbrzymiego okręgu, zabezpieczyło oświatę w duchu narodowym pierwszej generacji porozbiorowej na Litwie i Rusi. Zarówno w pracy naukowej, jak w twórczości artystycznej zaznaczył się udział Wilna wybitny"2.

* Dr, Uniwersytet Rzeszowski, Wydział Filologiczny, Instytut Filologii Polskiej, Zakład Literatury Staropolskiej i Polskiego Oświecenia, ul. Rejtana 16C; 35-959 Rzeszów; e-mail: konkret73@wp.pl

${ }^{1}$ J. Zawadzki do ks. A. K. Czartoryskiego [Wilno, 20 września 1814], w: Materiały do dziejów literatury $i$ oświaty na Litwie i Rusi z archiwum drukarni i księgarni Józefa Zawadzkiego w Wilnie z lat 1805-1865, t. 1, zebrał T. Turkowski, Drukarnia Józefa Zawadzkiego, Wilno 1935, s. 86.

${ }^{2}$ Materiaty do dziejów..., s. 16. 
Podobnego przekonania była również Alina Witkowska, pisząc, iż stolica Litwy odegrała podówczas wielką rolę „Aten polskich” dzięki temu, że w jej granicach istniała ta nieoceniona uczelnia. Badaczka dodaje, że to właśnie za sprawą bardzo prężnie działającego uniwersytetu miasto przeżyło w początkach XIX wieku swoje spóźnione oświecenie ${ }^{3}$. Dał on Wilnu wielu wybitnych intelektualistów, co w zasadniczy sposób zaważyło na atmosferze kulturalnej, ogólnej świadomości i wyobrażeniach jego mieszkańców, a co za tym idzie, na całokształcie stylu życia miasta.

To właśnie z Uniwersytetem Wileńskim związał też początkowo swą karierę zawodową Józef Zawadzki. Po zaledwie dwóch latach pobytu w Wilnie, w 1805 roku, podpisał on z władzami uczelni umowę na dzierżawę podupadłej uniwersyteckiej drukarni. Dodajmy, że był już wówczas dość dobrze obeznany z rynkiem księgarskim z racji licznych praktyk, które odbył w księgarniach Poznania, Wrocławia czy Lipska, i potrafił właściwie ocenić stan oraz potrzeby wileńskiej typografii. Dostrzegał na tym polu wiele braków i zaniedbań, ale widział także szansę na wykazanie się przedsiębiorczością i zbudowanie od podstaw firmy wydawniczo-księgarskiej, dorównującej tego typu instytucjom znanym z Europy zachodniej. W pomyślnej realizacji całego przedsięwzięcia wspierany był od samego początku przez ks. Adama Kazimierza Czartoryskiego ${ }^{4}$, z którym połączyła go długoletnia przyjaźń. Jak pisze Radosław Cybulski:

Kontakty tych dwóch ludzi były znamienne dla okresu, w którym się rozwijały. Czartoryski kontynuował tradycje mecenatu magnackiego, popierając przedsiębiorcę, który dążył do tego, aby ekonomikę oprzeć nie na datkach i wsparciach, lecz na działaniu kapitalistycznego rynku towarowego. Zawadzki pragnął przekazać mecenat $\mathrm{w}$ ręce publiczności czytelniczej. Zdawał sobie sprawę z tego, że „odbyt księgarskich produktów” będzie stanowił o powodzeniu firmy, którą zakłada15.

Niezwykle ważną rolę w tym procesie „zbytu księgarskich produktów” odgrywała, jak wiadomo, prasa periodyczna, na której łamach - począwszy od XVIII wieku - rozpowszechniano informacje na temat aktualnej produkcji piśmienniczej. Zdawał sobie z tego doskonale sprawę i Zawadzki, tłoczący tuż po wydzierżawieniu uniwersyteckiej drukarni „Dziennik Wileński” (1805-1806) oraz „Gazetę Literacką Wileńską” (1806). Obydwa periodyki zawierały dział poświęcony wydawniczym nowościom, a „Gazeta Literacka” publikowała ponadto sporo recenzji. Na marginesie należy dodać, że Zawadzki przygotował nawet General-

${ }^{3}$ A. Witkowska, Rówieśnicy Mickiewicza. Życiorys jednego pokolenia, Oficyna Wydawnicza Rytm, Warszawa 1998, s. 26-33.

${ }^{4}$ Zawadzki uzyskał od generała ziem podolskich pożyczkę, którą wraz z własnym funduszem i pożyczką od Uniwersytetu zainwestował w rozwój drukarni.

${ }^{5}$ R. Cybulski, Józef Zawadzki - księgarz, drukarz, wydawca, Ossolineum, Wrocław 1972, s. 39. 
ne przepisy dla literatów, których recenzje maja być umieszczane w powszechnej gazecie literackiej, określające dokładnie, jakie dzieła mają być recenzowane, jak obszerne mają być recenzje itd. Nie był to wprawdzie dokument oryginalny, lecz tłumaczenie przepisów dla którejś z gazet literackich w Niemczech, sporządzone przez Zawadzkiego zapewne dla współpracowników drukowanej przez niego „Gazety Literackiej Wileńskiej”. Gros bowiem spośród ukazujących się w tym periodyku recenzji to omówienia aktualnych wydawnictw wileńskich, mające charakter raczej popularyzatorski niż krytyczno-naukowy ${ }^{6}$. Stanowiły one rodzaj reklamy dla książek wydawanych przez uniwersyteckiego typografa ${ }^{7}$.

Kiedy wraz z grudniem 1806 roku skończył się wydawniczy żywot obydwu wspomnianych czasopism, w obiegu informacji na temat aktualnej produkcji piśmienniczej zaistniała dotkliwa luka, na którą wielokrotnie wskazywał właśnie Zawadzki. Dokładał przy tym wielu starań, aby na nowo ożywić wileńską prasę periodyczną. Zabiegi zmierzające do reaktywowania wydawanego w latach 1805-1806 „Dziennika Wileńskiego” podejmował już około roku 1809, o czym dowiadujemy się z jednego z listów adresowanych do ks. Adama Kazimierza Czartoryskiego. Przedsiębiorczy edytor na możliwości takie zapatrywał się dość optymistycznie. Dwunastego października 1809 roku pisał do księcia generała:

\begin{abstract}
Przeszły nieboszczyk Dziennik szedł jako tako. Prenumeratorów miał dosyć i na laboratorach nie zbywało. Skład tylko redakcji, może dlatego, że liczny, nie dał się w spojeniu utrzymać. Utrzymanie takowego pisma nie może być u nas trudne, potrzeba tylko zdaje się napędzania. Co zapewne za bytności Kuratora nastąpi. Wszelakoż nim do tego przyjdzie, ja zawsze o tym myślę i kogo mogę namawiam, bo z niedostatku tego czuję szkody. Oto nawet nie ma gdzie księgarskich wiadomości ogłaszać. Gazeciarz nasz, wydawca Kuriera Litewskiego, onych nie lubi i zniesienie się z nim w tej mierze trudne ${ }^{8}$.
\end{abstract}

${ }^{6}$ Kwestie te szczegółowo omawia Antoni Szantyr (Groddeck jako recenzent i redaktor, w: Z dziejów filologii klasycznej w Wilnie, red. J. Oko, Drukarnia Krajowa, Wilno 1937, s. 211-227).

${ }^{7}$ Dla przykładu, w recenzji tragedii Sofoklesa Filoktet, wydanej w Wilnie w 1806 r. drukiem i nakładem Józefa Zawadzkiego, Gotfryd Ernest Grodek podkreślając ofiarność typografa, rozwodzi się bardzo szczegółowo nad brakiem szkolnych wydań, od których jakości w dużej mierze - jak sądzi - zależy podniesienie stanu wileńskiej filologii (zob. „Gazeta Literacka Wileńska” 1806, cz. II, nr 41, s. 236-239). Te same uwagi pojawiają się też w recenzji greckiej chrestomatii Friedricha Jacobsa (opublikowanej w 1805 r. w Jenie w oficynie Frommana) uzupełnione wyrażeniem nadziei, że w niedługim czasie pojawi się podręcznik języka greckiego dla polskiej młodzieży uczącej się w gimnazjach i w wyższych klasach szkół powiatowych (zob. „Gazeta Literacka Wileńska” 1806, cz. II, nr 36, s. 156-160). Sugestia ta nie pozostała bez echa i już w grudniu tego samego roku wydrukował Zawadzki wychodzący naprzeciw oczekiwaniom podręcznik opracowany przez Sebastiana Żukowskiego (Poczatki języka greckiego, Wilno 1806).

${ }^{8}$ T. Turkowski, Nieznane materiaty historyczno-literackie $w$ archiwum Zawadzkich $w$ Wilnie, Osobne odbicie ze Sprawozdań Polskiej Akademii Umiejętności, T. XXXVI, nr 10, Warszawa 1931, s. 16. 
Do sprawy tej powrócił Zawadzki w roku następnym, kiedy zbliżał się już termin planowanego przyjazdu do Wilna ks. Kuratora - Adama Jerzego Czartoryskiego. W korespondencji skierowanej do jego ojca czytamy:

Na końcu tego miesiąca [tj. maja 1810 roku - przyp. J.K.], a najdalej w przyszłym, oczekujemy tu przybycia Książęcia Kuratora. Po krzątaniu się i ruchu, jaki teraz w całej naszej Akademii panuje, wnosimy, że Książę Kurator ściśle wejrzy w postępek nauk. Ja też sobie robię nadzieję, że przy pomocy W.X. Mości uda nam się odkopać „Dziennik Wileński”, którego wskrzeszenia z niecierpliwością oczekują9 .

Największą bolączką dla uniwersyteckiego typografa, jak wynika z dalszej części cytowanego listu, był brak czasopisma, na którego łamach znalazłoby się miejsce na informacje o wydawniczych nowościach oraz zapowiedzi dzieł mających się dopiero ukazać:

Nie uwierzysz W.X. Mość, jak trudno u nas umieścić w jakiem piśmie wiadomość o nowo wyszłych dziełach. W „Kurierze Litewskim”, który w drukarni XX. Pijarów wychodzi, nic umieszczać nie można. Dlatego zrobiłem projekt, że gdyby „Dziennik Wileński”, na wieczny skazany był spoczynek, wydawać co miesiąc „Wiadomości księgarskie” i te gratis po kraju rozrzucać... ${ }^{10}$

Konsekwencje zaistniałej sytuacji były, zdaniem Zawadzkiego, najdotkliwsze dla literatury, która - czytamy w kolejnym liście do Czartoryskiego - ,jak nieżywa, żadnej o sobie nie daje wiadomości. Nie masz drogi do rozgłaszania i tego, co mamy. Nie masz trybunału na krytykę. I wreszcie jest to krzywda dla naszej prowincji i miasta, że w takim natłoku ludzi, naukom poświęconych, żadnego nie ma pisma periodycznego, na czym w lichym gdzie indziej miasteczku nie zbywa"11. Niestety, plany te spełzły na niczym, prawdopodobnie również z uwagi na ówczesną sytuację polityczną, co byłoby kolejnym potwierdzeniem Cyceronowej refleksji ,,inter arma silent Musae”. Trudno bowiem w jakikolwiek inny sposób wytłumaczyć fakt, iż prasa polska w Wilnie, która tak szybko się rozwijała i rokowała duże nadzieje na przyszłość (przypomnijmy, że w latach 1804-1806 wychodziły dwie gazety, dwa miesięczniki i tygodnik) tak nagle upadła.

Dopiero po przejściu „napoleońskiej zawieruchy” w kręgach uniwersyteckich można zaobserwować ponowne wzmożone zainteresowanie czasopiśmiennictwem. Także i Zawadzki - w porozumieniu z Adamem Kazimierzem Czartoryskim - powrócił w roku 1814 do realizacji swoich wcześniejszych zamierzeń, proponując ówczesnemu rektorowi Uniwersytetu Wileńskiego - Janowi Śniadeckiemu utworzenie

\footnotetext{
${ }^{9}$ Tamże, s. 45.

${ }^{10}$ Tamże, s. 45-46.

${ }^{11}$ Tamże, s. 48-49.
} 
uczelnianego periodyku na wzór przygotowywanego w Warszawie „Pamiętnika”l2 . Uczony propozycję tę przyjął i zobowiązał się do dostarczenia, z początkiem następnego roku, trzech arkuszy tekstu do publikacji. Dokument erygujący „Dziennik Wileński” podpisali oprócz niego: brat Jędrzej Śniadecki, ks. Stanisław Bonifacy Jundziłł, Gotfryd Ernest Grodek, August Bécu, Jakub Szymkiewicz oraz Kalikst Daniłowicz. Wytrwały i konsekwentny w swym zamyśle typograf przekonywał sceptyków, których prawdopodobnie nie brakowało, że:

Takowe pisma we wszystkich krajach są i środkiem powszechniejszego oświecenia i onego miarą. Ich niedostatek nie tylko szkodliwy jest bardzo, ale nadto powód daje do formowania najgorszej opinii, która tym więcej krzywdzi, kiedy jej prawdziwości zaprzeć nie można. Pospolicie z pism periodycznych sądzą o stopniu narodowej instrukcji. To mając na względzie, spodziewać się potrzeba, że kochający honor narodowy zechcą wspierać przedsięwzięcia w tej mierze i nie będą nazywać zbytkiem, kiedy kilka pism periodycznych wychodzić zacznie ${ }^{13}$.

W istocie, obok „Dziennika Wileńskiego”, w roku 1815 powołano jeszcze „Tygodnik Wileński”, noszący taki sam tytuł, jak jego poprzednik z roku 1804. W następnym roku zaczęły być z kolei wydawane „Wiadomości Brukowe” oraz „Pamiętnik Magnetyczny Wileński”. Znamienne, iż Zawadzki w przedsięwzięciach tych nie dostrzegał zagrożenia dla tłoczonego u siebie „Dziennika...”, choć przecież wiązało się to $\mathrm{z}$ wysokim ryzykiem niedostatku prenumeratorów, co było zazwyczaj główną przyczyną upadku wielu tego rodzaju inicjatyw na rynku czasopiśmienniczym. Wręcz przeciwnie, konkurencyjne tytuły oraz prowadzone nieraz na ich łamach wzajemne polemiki ożywiały, jego zdaniem, życie kulturalne kraju i korzystnie wpływały na stan oświecenia publicznego. W mniemaniu światłego typografa miał to być zasadniczy cel, do którego powinny dążyć wszystkie wydawane podówczas periodyki.

Pieczę redaktorską nad ukazującym się od stycznia 1815 roku „Dziennikiem..." objął Kazimierz Kontrym, a wydawcą został oczywiście Zawadzki, który jednak dość szybko zorientował się, że jego oczekiwania względem profilu tego

${ }^{12}$ Zawadzki, w ścisłym porozumieniu z ks. Adamem Kazimierzem Czartoryskim, bardzo angażował się w powstanie tego stołecznego czasopisma. Osobiście jeździł z Wilna do Warszawy, by pozyskać dlań współpracowników i Feliksa Bentkowskiego jako redaktora. Wielu starań dołożył także w powołanie do istnienia „Pamiętnika Lwowskiego”. Zdaniem Wiesława Pusza, „Pamiętnik Warszawski”, „Dziennik Wileński” i „Pamiętnik Lwowski” „była to w gruncie rzeczy jedna i ta sama kampania zmierzająca do wydawania w Warszawie, Wilnie i Lwowie pism periodycznych, podjęta przez Czartoryskich w przededniu rozpoczęcia Kongresu Wiedeńskiego, a dowodząca dalekowzroczności i stałego zresztą kojarzenia interesów rodu i narodu” (W. Pusz, „Nowy Parnas” przedromantycznej Warszawy. Bruno Kiciński i grono jego wspótpracowników, Polska Akademia Nauk, Wrocław 1979, s. 31).

${ }^{13}$ Materiaty do dziejów..., s. 86. 
periodyku były nieco inne, aniżeli zespołu redaktorskiego. Otóż bardzo zależało mu, aby na łamach tego czasopisma zamieszczano artykuły krytyczne szczegółowo omawiające wydawnicze nowości, co - jak już wspominaliśmy - było niezwykle skuteczną formą ich reklamy. Niestety, w reaktywowanym „Dzienniku Wileńskim" nie pojawiały się one zbyt często. Kazimierz Kontrym (redaktor naczelny w latach 1815-1817) nie przewidywał bowiem w piśmie „uczonym” miejsca na dział krytyczno-literacki i obowiązek krytyki przerzucał na pisma specjalistyczne. Stąd kolejny pomysł Zawadzkiego, by ponownie wydawać „Gazetę Literacką Wileńską", która ukazując się w roku 1806 pod redakcją Grodka i Kontryma, właśnie krytycznemu roztrząsaniu dzieł polskich poświęcała najwięcej miejsca. Planów tych nie udało się jednak zrealizować. Uniwersytecki typograf pisał na ten temat w jednym z listów (z 1816 roku) do Feliksa Bernatowicza:

to tylko pewna, że nie jest na zawsze wygnana od nas krytyka, ale nie jest ona zamiarem „Dziennika”, do którego kilka artykułów krytycznych weszło przypadkowo, i jeszcze może kilka także przypadkowo i dla próby jedynie wejść może, a reszta odkłada się do przyszłej osobliwej gazety krytycznej, która kiedyż tedy może i zaprowadzi się stale tak, aby już nie ustawała. Owe artykuły krytyczne, które były już w „Dzienniku”, weszły do niego albo na żądanie autorów, albo na żądanie tych, co przez krytykę chcieli zrobić prędszy odbyt dzieła; jakoż to i pomogło, bo choć się gdzie nie wszystko chwali, jednakże wiadomość o dziele głośniejszą się stając, ułatwia dziwnie jego przedaż ${ }^{14}$.

Zawadzki, jak wynika z przywołanych listów, doskonale zdawał sobie sprawę $\mathrm{z}$ tego, jak ważnym narzędziem organizującym społeczny odbiór piśmiennictwa była właśnie prasa. Zrozumiałe są w związku z tym jego ustawiczne zabiegi o podtrzymanie ożywionego ruchu czasopiśmienniczego. Oczywiście, jak łatwo się domyśleć, starania te podyktowane były również interesem osobistym. Jako właścicielowi drukarni i największej w tamtym okresie wileńskiej księgarni, zależało mu na utrzymania płynności sprzedaży i w miarę szybkim zbywaniu wydawanych książek, w czym reklama prasowa była bardzo pomocna. Ponadto osobnym problemem, z którym wiązała się bezpośrednio kwestia potrzeby popularyzacji produkcji piśmienniczej na łamach prasy, był niski poziom ówczesnej

${ }^{14}$ Materiały do dziejów..., s. 127-128. Niechęć redaktorów „Dziennika...” do dopuszczania na jego łamy artykułów krytycznych na temat aktualnej produkcji piśmienniczej wynikała również - o czym pisał Zawadzki w tym samym liście - z przekonania, iż rodzimi krytycy nie posiadają należytej znajomości tego rzemiosła. Stąd propozycja, aby wpierw wydać w Wilnie dzieło zawierające dokładne i zupełne przepisy sztuki krytycznej, która - przekonywał - tak jak jest ważną i konieczną, tak też niestety i trudną. Przykładem współczesna krytyka dramatyczna, do której się rzucono, „a podług mniemania znawców, najwięcej w tym krytycy bredzą i opinię publiczną w błąd prowadzą" (tamże, s. 127). Zawadzki planował w związku z tym opublikowanie w swojej oficynie thumaczenia dzieła Williama Cooke'a, The elements of dramatic criticism (Londyn 1775). 
kultury czytelniczej, na co Zawadzki również niejednokrotnie utyskiwał w swej rozlicznej korespondencji. Refleksje na ten temat pojawiają się, na przykład, w cytowanym już liście (z 1816 roku) adresowanym do sekretarza ks. Adama Kazimierza Czartoryskiego - Feliksa Bernatowicza:

Mało kto kupuje książki, żaden ich urzędnik, żaden pleban do oświecenia się w swoim obowiązku nie potrzebuje. [...] Bardzo niewielka jest liczba takich, co kiedy niekiedy kilka szostaków odważą na kupienie książek dla zaspokojenia ciekawości. Nie masz takiego dzieła w polskim języku, któregoby zwyczajnym sposobem można było w księgarniach przedać w jednym roku pięćset egzemplarzy, chociaż jest kilkanaście milionów ludu języka polskiego; a przecież i odbyt roczny pięciuset egzemplarzy nie jest jeszcze dostatecznym do wynagrodzenia i kosztów druku i prac pisarzów, osobliwie takich, coby i godni byli, i chcieli żyć jedynie z pisarskiego rzemiosła, nie dla samej tylko sławy pracując, bo primo vivere quam philosophari. Nasi literaci polscy piszą po większej części przez gorliwość jedynie, a zagranicą mają tacy za pisanie swoją zapłatę. Nasi też nie mogą całkowicie poświęcić się pisarskiemu rzemiosłu, bo ich zajmują więcej roboty inne, z których żyją. Dlatego też wytrwanie ich w ochocie i gorliwości, jako różnym przypadkom podległe, jest niepewne. I długo jeszcze takim będzie, póki się gust do czytania nie wzmoże, a tym samym i rzemiosła autorskiego zyskowniejszym nie uczyni: zwłaszcza, że niewielu jest o to dbających. Wszakże oprócz naszego księcia nie słychać nigdzie o mecenasach i protektorach Muz polskich ${ }^{15}$.

Przywołany fragment korespondencji sporo mówi o sytuacji na rynku księgarskim i o kondycji czytelnictwa na Litwie w pierwszych dziesięcioleciach XIX wieku. Wydaje się przy tym, iż nikt inny nie mógł być w tej kwestii lepiej zorientowanym niż właśnie Zawadzki, dla którego, z racji wykonywanej profesji, problemy te stanowiły niejako chleb powszedni. Fakty nie napawały jednak optymizmem; nabywanie i czytanie książek nie należały, jak się okazuje, do elementarnych nawyków ówczesnego społeczeństwa. Doświadczony wileński wydawca wiedział, że to właśnie prasa periodyczna miała w tym względzie do odegrania niebagatelną rolę. Stąd, między innymi, ustawiczne i wytrwałe starania, by podtrzymać ożywiony ruch na rynku czasopism, na których łamach powiadamiano by potencjalnych czytelników o aktualnie dostępnej produkcji piśmienniczej, publikowano recenzje i omówienia, mające za zadanie zainteresować odbiorców dostępnymi na rynku księgarskim nowościami.

Reaktywowany „Dziennik Wileński” ukazywał się w drukarni Zawadzkiego tylko do roku 1818, a następnie jego wydawaniem zajęła się oficyna Antoniego Marcinowskiego. To właśnie z jego inicjatywy zawiązana została spółka kapitałowa pod

${ }^{15}$ Materiały do dziejów..., s. 126. 
nazwą Towarzystwa Typograficznego i od kwietnia wspomnianego roku przejęło ono nad zagrożonym w swym dalszym istnieniu periodykiem całkowitą pieczę ${ }^{16}$. Zawadzki skupił się wówczas przede wszystkim na działalności księgarskiej i unowocześnieniu drukarni, aczkolwiek niejednokrotnie, czy to na łamach „Dziennika” czy „Tygodnika Wileńskiego” (poza tym także prasy warszawskiej i lwowskiej) spotkać można było bardzo wiele ogłoszeń dotyczących prenumeraty oraz dostępnych $\mathrm{w}$ jego księgarni wydawniczych nowości. Jako wytrawny edytor w pełni doceniał bowiem popularyzacyjny potencjał pism periodycznych i wiedział, że jest to najlepsza droga do anonsowania aktualnych wydarzeń na rynku księgarskim.

Aktywna działalność Zawadzkiego na rzecz rozwoju czasopiśmiennictwa polskiego na Litwie niepozbawiona była jednak przeszkód. Na różnorakie trudności, z którymi wileński typograf musiał się zmierzyć, wskazywał Tadeusz Turkowski, pisząc:

\begin{abstract}
Rozbicie kraju, jego wielkie braki techniczne i kulturalne, ospałość społeczeństwa i panowanie cudzoziemszczyzny, przewlekłe wojny, przerywające komunikację z Zachodem, utrudnienia graniczne i cenzuralne - nie zdołały osłabić energii Zawadzkiego, który dążył do objęcia swoją działalnością nie tylko Wilna i ogromnego Okręgu Wileńskiego, lecz także i innych dzielnic i usiłował zorganizować ruch umysłowy i obieg książki w podzielonej Polsce. Środkami do tego miały być prace nad bibliografią polską oraz czasopisma literackie i Zawadzki wiele starań poświęcił jednej i drugim ${ }^{17}$.
\end{abstract}

Reasumując, należy jeszcze raz podkreślić, iż Zawadzki, jako animator wielu ważnych inicjatyw około wydawania pism periodycznych, niezwykle efektywnie przyczyniał się do podtrzymania i rozwoju ruchu czasopiśmienniczego na Litwie doby porozbiorowej. Wszystkie podejmowane przez niego w tym kierunku działania wynikały z przekonania, że czasopisma wpłyną bardzo pozytywnie na życie kulturalne kraju, będą przy tym miejscem twórczej krytyki oraz anonsów wydawniczych i księgarskich. Zależało mu na tym zarówno jako doświadczonemu edytorowi, dla którego ocena wydawanych dzieł była bardzo pomocna w sukcesywnym podejmowaniu kolejnych inicjatyw wydawniczych, jak i księgarzowi dbającemu o to, aby informacja o dostępnej produkcji piśmienniczej docierała do jak najszerszego kręgu odbiorców i budziła ich zainteresowanie.

\title{
Bibliografia
}

Beauvois Daniel, Wilno - polska stolica kulturalna zaboru rosyjskiego 1803-1831, przeł. Ireneusz Kania. Wydawnictwo Uniwersytetu Wrocławskiego, Wrocław 2010.

${ }^{16}$ Notabene wśród wielu członków tego Towarzystwa znajdujemy również Józefa Zawadzkiego.

${ }^{17}$ T. Turkowski, Początki „Pamiętnika Warszawskiego” w r. 1814, „Pamiętnik Warszawski” 1931, R. III, z. 10-12, s. 171. 
Ciechowski Wacław, Czasopisma polskie na Litwie [1760-1864]. „Kwartalnik Litewski” 1910, R. I, t. 2, s. 39-66; t. 3, s. 14-40; t. 4, s. 67-96; 1911, R. II, t. 5, s. 101-124.

Cybulski Radosław, Józef Zawadzki - księgarz, drukarz, wydawca, Ossolineum, Wrocław 1972.

Cybulski Radosław, Józef Zawadzki - twórca nowoczesnego ruchu wydawniczego w Polsce, w: Wilno i Kresy Pótnocno-Wschodnie. Kultura i trwanie, t. 2, red. Elżbieta Feliksiak i Alicja Kisielewska, Towarzystwo Literackie im. Adama Mickiewicza, Białystok 1996, s. 315-326.

Kucharzewski Jan, Czasopiśmiennictwo polskie wieku XIX w Królestwie, na Litwie i Rusi oraz na emigracji, Gebethner i Wolff, Warszawa 1911.

Materiaty do dziejów literatury i oświaty na Litwie i Rusi z archiwum drukarni i księgarni Józefa Zawadzkiego w Wilnie z lat 1805-1865, t. 1, zebrał Tadeusz Turkowski, Drukarnia Józefa Zawadzkiego, Wilno 1935.

Pusz Wiesław, ,,Nowy Parnas” przedromantycznej Warszawy. Bruno Kiciński i grono jego wspótpracowników, Polska Akademia Nauk, Warszawa 1979.

Szantyr Antoni, Groddeck jako recenzent i redaktor, w: Z dziejów filologii klasycznej w Wilnie, red. Jan Oko, Drukarnia Krajowa, Wilno 1937, s. 180-231.

Turkowski Tadeusz, Nieznane materiaty historyczno-literackie $w$ archiwum Zawadzkich $w$ Wilnie, t. XXXVI, nr 10, osobne odbicie ze Sprawozdań Polskiej Akademii Umiejętności, Warszawa 1931.

Turkowski Tadeusz, Początki „Pamiętnika Warszawskiego” w r. 1814, „Pamiętnik Warszawski” 1931, R. III, z. 10-12, s. 170-176.

Witkowska Alina, Rówieśnicy Mickiewicza. Życiorys jednego pokolenia, Oficyna Wydawnicza Rytm, Warszawa 1998.

\section{Jolanta Kowal}

\section{Role of the Vilnius editor Józef Zawadzki in the development of the Polish periodical press in Lithuania in the partition age}

\section{(Summary)}

Józef Zawadzki, the Vilnius bookseller and the editor, the animator of many important publishing undertakings, contributed extremely effectively to sustaining and the development of the scientific-literary movement in Lithuania in the partition age. Moreover, he became involved very actively in coming into existence and publishing periodicals. He spared no effort to publish "Vilnius Daily" (in both periods of appearing it) or "Vilnius Literary Newspaper". All action taken in this direction resulted from Zawadzki's belief that magazines would influence the cultural life of the country very positively and be a place of the constructive criticism, as well as publishing and book advertisements. He cared about it both as the experienced editor, for whom the evaluation of published work was extremely helpful in gradual developing publishing successive initiatives, and for the bookseller caring for the information about the available writing production so that it could get through to the widest circle of recipients and arouse their interest.

Keywords: "Dziennik Wileński" ("Vilnius Daily"); “Gazeta Literacka Wileńska" ("Vilnius Literary Newspaper”); Józef Zawadzki; Lithuania; book announcements; periodic press; Vilnius University; Vilnius

Słowa kluczowe: „Dziennik Wileński”; „Gazeta Literacka Wileńska”; Józef Zawadzki; Litwa; ogłoszenia księgarskie; prasa periodyczna; Uniwersytet Wileński; Wilno 